\title{
Peran Dukungan Sosial dalam Meningkatkan Resiliensi pada Remaja Panti Asuhan
}

\author{
Febry Isnaini ${ }^{1}$, Abdul Muhid ${ }^{2}$ \\ \# Universitas Islam Negeri Sunan Ampel Surabaya \\ E-mail:isnainifebry@gmail.com \\ *Universitas Islam Negeri Sunan Ampel Surabaya \\ E-mail:abdulmuhid@uinsby.ac.id
}

\begin{abstract}
Adolescence can be interpreted as a period of transition of an individual from childhood developing to adulthood. Adolescents are usually associated with periods of change in their life processes. When the individual reaches the age of adolescence, they will begin to think about how their life will be in the future. Adolescents must have great confidence and strong determination so they can quickly get back up from the difficulties in their lives. For every teenager and especially for orphanage youth, of course it is necessary to have the capability to overcome life's difficulties and problems to immediately rise to become a useful and reliable person in carrying out commitments to theirself and the people around them in the future. There are many factors that can influence a person's level of resilience, and one of them is social support. This study aims to see the role of social support in increasing resilience in orphanage youth. This research was conducted using the literature study method. Research with this model is carried out by searching and collecting reference materials from journals and articles based on the variables being studied. After doing this research, it was found that social support had an effect on increasing the resilience of orphanage youth.
\end{abstract}

Keywords: Resilience; Social Support; Orphanage Youth.

\section{PENDAHULUAN}

Remaja dapat diartikan sebagai masa peralihan seorang individu dari masa anak-anak yang berkembang menuju kedewasaaan, dimana dalam masa ini akan ditemui banyak peralihan dalam diri individu tersebut (Wasono, 2019). Remaja merupakan generasi muda yang diharuskan untuk memiliki kepribadian yang teguh sehingga mampu turut ikut andil dalam membangun Negeri menjadi lebih baik kedepannya. Dalam menjalani kehidupan mereka di waktu mendatang, remaja harus mempunyai keyakinan yang besar serta tekad yang kuat untuk mampu segera kembali bangkit dari kesulitan-kesulitan dan pengalaman-pengalaman yang kurang menyenangkan yang terjadi dalam kehidupannya (Masnina, 2017). Masa remaja akan dipenuhi dengan gejolak dan guncangan serta permasalahan yang mulai muncul dalam kehidupannya (Dewi \& Henu, 2015).

Remaja yang hidup di panti asuhan biasanya adalah individu yang kehilangan keluarga, khususnya orang tua karena telah meninggal dunia atau berpisah, faktor ekonomi yang kurang mendukung, kondisi keluarga yang kacau/kurang harmonis, kurang mampunya orangtua dalam memberikan perhatian dan pemenuhan keperluan hidup anak mereka, serta broken home yang mengakibatkan fungsi keluarga itu hilang, sehingga anak kurang menerima perhatian dari orangtuanya (Mazaya \& Supradewi, 2011). Remaja panti asuhan mempunyai beberapa permasalahan didalam proses tumbuh kembangannya, antara lain adalah cenderung lebih gampang mengalami depresi dan stres, serta sering merasa tertekanan dan mengalami masalah-masalah di hidupnya (Tricahyani \& Widiasavitri, 2016). Remaja yang hidup di panti asuhan dituntut untuk dapat berjuang sendiri ketika menghadapi luapan emosi serta masalah-masalah yang timbul tanpa didampingi oleh keluarga, telebih lagi sosok orang tua yang seharusnya bisa dijadikan model dan sumber kasih sayang (Dewi \& Henu, 2015).

Data dari aplikasi SIKS NG per Mei 2021 dari 3.914 Lembaga Kesejahteraan Sosial Anak (LKSA) memperoleh hasil bahwa sebanyak 191.696 anak berada dalam pengasuhan LKSA, LKSA sendiri meliputi Yayasan, Panti Asuhan, atau Balai. Melalui perhitungan tersebut, terdapat 33.085 yatim, 7.160 piatu, serta 3.936 yatim piatu, sehingga total keseluruhannya adalah sebanyak 44.181 jiwa (Setiawan, 2021). Yatim adalah individu yang kehilangan sesorang ayah karena telah wafat, piatu adalah individu yang kehilangan seorang ibu karena telah wafat, sedangkan yatim piatu adalah individu yang kehilangan kedua orangtuanya, yakni ayah dan ibu karena telah wafat (Muliawiharto \& Masykur, 2020).

Panti asuhan diartikan sebagai sebuah lembaga kesejahteraan sosial yang memiliki tujuan memberikan bantuan kepada anakanak yang sudah tidak memiliki ayah atau ibu, maupun keduanya (Ester et al., 2020). Panti asuhan ialah tempat yang diperuntukkan bagi anak-anak yang tidak mempunyai orangtua karena telah meninggal dunia, mereka yang sengaja ataupun 
yang tidak sengaja ditinggal dan ditelantarkan oleh orangtuanya, maupun mereka yang sebenarnyaa masih mempunyai orangtua lengkap tetapi hidup dalam kekurangan finansial (Purwanti \& Aulia, 2017). Panti asuhan didefinisikan sebagai suatu lembaga untuk membangun pertumbuhan dalam hal psikis maupun fisik bagi anak-anak yang kehilangan keluarga dan anak-anak yang hidup tidak satu rumah bersama keluarganya. Sehingga, panti asuhan disini memiliki peran dalam menggantikan sosok keluarga dalam hal pemenuhan kebutuhan yang diperlukan oleh anak-anak dalam masa tumbuh kembangnya (Tricahyani \& Widiasavitri, 2016).

Setiap individu pasti pernah mengalami kegagalan, keterpurukan, kesulitan, dan bahkan peristiwa traumatis yang memberikan dampak negatif bagi kehidupan mereka (Purwanti \& Aulia, 2017). Remaja yang kehilangan orangtua pasti akan mengalami beberapa tekanan dan kesulitan dalam kehidupannya, misalnya aktivitas sehari-harinya akan berubah, kesulitan dalam perekonomian, serta tidak mempunyai tempat yang bisa dijadikan sebagai hunian tetap (Apelian \& Nesteruk, 2017). Bebarapa kesulitan yang dihadapi oleh remaja dalam mengatasi permasalahan dalam hidup dapat dipermudah dengan adanya resiliensi. Resiliensi sendiri bisa diartikan sebagai sebuah dorongan dari dalam diri untuk menguatkan motivasi seseorang untuk kembali berdiri tegak dalam menghadapi segala permasalahan yang terjadi (Ester et al., 2020). Resiliensi perlu dikembangkan karena memiliki manfaat bagi seorang individu sebagai upaya dalam menghadapi segala macam tantangan dan kesulitan dalam hidup (Purwanti \& Aulia, 2017). Panti asuhan dijadikan sebagai tempat untuk saling berinteraksi diantara penghuni panti asuhan tersebut, yang mana interaksi itu sendiri sangat diperlukan untuk dilakukan didalam lingkungan panti asuhan. Selain itu, resiliensi juga diperlukan oleh anak-anak panti asuhan sebagai pedoman dalam upaya penyelesaian masalah, mengatasi kesulitan, serta mengurangi kemungkinan terjadinya pelanggaran di panti asuhan (Masnina, 2017).

Resiliensi seseorang dipengaruhi banyak faktor, antara lain faktor yang berasal dari dalam dan luar diri individu. Fakkor dari luar diri individu sendiri ada banyak, dan Salah satunya ialah dukungan sosial (Sun \& Stewart, 2007). Dukungan sosial ialah suatu hubungan yang didalamya akan terjadi suatu pemberian bantuan yang diberikan kepada seorang individu dengan melibatkan interaksi dengan lingkungannya, yang mana dukungan sosial ini bisa berupa banyak hal seperti pemberian informasi, pemberiaan penghargaan, pemberian perhatian secara emosional, serta pemberian bantuan instrumental (Kumalasari \& Ahyani, 2012). Apabila lingkungan disekitarnya dapat memberikan dan menyebarkan banyak dukungan sosial yang bersifat positif kepada seorang individu, maka besar kemugkinan bahwa seorang individu tersebut dapat bangkit dari keterpurukan dan kesulitan serta mampu bertahan dalam segala rintangan yang terjadi di hidupnya (Syifa et al., 2021). Dukungan sosial bagi remaja panti asuhan tidak hanya didapatkan melalui pengasuhnya saja, melainkan bisa pula didapatkan dari penghuni panti asuhan lainnya (Tricahyani \& Widiasavitri, 2016). Berdasarkan beberapa hal diatas, maka penelitian ini perlu dilakukan untuk memberikan pengetahuan mengenai peran dukungan sosial dalam meningkatkan resiliensi remaja panti asuhan.

\section{METODE PENELITIAN}

Penelitian ini termasuk dalam jenis penelitian kualitatif. Metode yang digunakan dalam penelitian ini adalah metode literature review. Dimana sumber referensi yang dipakai dalam penelitian ini adalah beberapa jurnal ilmiah dan buku dengan berdasar pada variabel penelitian. Adapun beberapa referensi yang dijadikan sebagai pedoman dalam penulisan artikel ini adalah:

Tabel 1.

Referensi Pedoman

\begin{tabular}{|l|l|l|}
\hline \multicolumn{1}{|c|}{ Judul } & \multicolumn{1}{|c|}{ Penulis } & \multicolumn{1}{|c|}{ Sumber } \\
\hline $\begin{array}{l}\text { Hubungan Antara Dukungan Sosial } \\
\text { dengan Resiliensi pada Remaja Awal } \\
\text { Penghuni Panti Asuhan Bani Yaqub } \\
\text { Surabaya }\end{array}$ & Khairuddin Barbarosa, dkk & Google Scholar \\
\hline $\begin{array}{l}\text { Hubungan Dukungan Sosial Teman } \\
\text { Sebaya Terhadap Tingkat Resiliensi } \\
\text { Remaja Panti Asuhan }\end{array}$ & Landa Octa Mulia, dkk & Google Scholar \\
\hline $\begin{array}{l}\text { Hubungan Antara Dukungan } \\
\text { Emosional Pengasuh dengan Resiliensi } \\
\text { pada Remaja Panti Asuhan di } \\
\text { Kecamatan Tembalang Ali Muliawiharto \& Achmad }\end{array}$ & Google Scholar \\
\hline $\begin{array}{l}\text { Perbedaan Resiliensi Antara Remaja } \\
\text { yang Hidup dalam Keluarga Lengkap, } \\
\text { Keluarga Single Parent, dan Remaja } \\
\text { yang Hidup di Panti Asuhan }\end{array}$ & Lailatuzzahro Al-Akhda Aulia & \\
\hline $\begin{array}{l}\text { Prediksi Self-Esteem, Social Support, } \\
\text { dan Religiusitas Terhadap Resiliensi }\end{array}$ & Reza Pahlevi, dkk & \\
\hline $\begin{array}{l}\text { Hubungan Antara Dukungan Sosial } \\
\text { dengan Penyesuaian Diri Remaja di } \\
\text { Panti Asuhan }\end{array}$ & Fani Kumalasari \& Latifah Nur & Google scholar \\
\hline
\end{tabular}

Proses pencarian referensi dilakukan dengan melalui pencarian digital menggunakan situs-situs kredibel seperti google scholar, garuda, researchGate, dan lain-lain. Proses pencarian referensi juga dilakukan dengan melalui penentuan kata kunci 
dari setiap variabel yang digunakan, diantaranya adalah: resiliensi, dukungan sosoial, remaja panti asuhan, hubungan dukungan sosial dan resiliensi. Setelah melakukan pencarian referensi, maka akan dilakukan penyaringan serta analisis jurnal yang sesuai dengan penelitian yang dibuat.

\section{HASIL DAN PEMBAHASAN}

\section{A. Resiliensi}

Resiliensi ialah suatu kapabilitas yang dimiliki oleh seseorang untuk mengatasi masa sulit dan permasalahan dalam hidupnya serta berusaha untuk menjaga kesehatan fisik agar nantinya mampu menjalani kehidupan dengan baik dan memiliki energi yang kuat dalam melanjutkan kehidupan (Setyowati et al., 2010). Menurut Walsh (2006) Resiliensi ialah suatu kapabilitas untuk bangkit dan segera pulih dari kesulitan serta dapat mengatasi tantangan hidup. Sedangkan Portzky et al. (2010) mendefinisikan resiliensi sebagai karakter individu yang mampu mengurangi pikiran-pikiran yang negatif serta merangsang adanya orientasi positif terhadap kesulitan dan stres yang sedang dialaminya.

Resiliensi merupakan suatu kehlian seseorang dalam menanggapi secara positif ketika ia dihadapkan pada permasalahan dan kesulitan, yang mana hal tersebut penting dalam proses pengelolaan tekanan hidup sehari-hari (Reivich \& Shatte, 2002; Alvina \& Dewi, 2017). Resiliensi menjadi salah satu faktor yang mampu menjadi pnegaruh dalam keberhasilan seseorang dalam mengatasi masa-masa sukar dalam hidup (Tunliu et al., 2019). Resiliensi memberikan kemungkinan bahwa seseorang ataupun sekelompok orang mampu untuk menangkal dan mengatasi setiap keadaan susah, sehingga resiliensi mampu mengubah seseorang menjadi pribadi yang lebih tangguh ketika menghadapi segala tantangan dalam hidup (Muliawiharto \& Masykur, 2020).

Menurut Grotberg (1995) terdapat tiga hal yang dapat mempengaruhi resiliensi seseorang, yaitu I Am, I Have, dan I Can. I Am berkaitan dengan kekuatan yang bersumber dari dalam dirinya sendiri. I Have ialah faktor yang memberikan pengaruh terhadap resiliensi yang berkaitan dengan dukungan eksternal, yang artinya hal tersebut berasal dari luar dirinya sendiri. $I$ Can merupakan bagian dari faktor yang mempengaruhi resiliensi yang berkaitan dengan keterampilan interpersonal dan kemampuan seseorang dalam menyelesaikan permasalahan hidup yang dialaminya.

Terdapat 7 aspek yang dapat membangun resiliensi dalam diri individu (Reivich \& Shatte,2002; Nisa \& Muis, 2016), yaitu:

1. Regulasi Emosi, yakni kapasitas individu untuk mengendalikan emosi dan berusaha untuk tetap tenang ketika menghadapi tekanan.

2. Pengendalian Dorongan, yakni kapabilitas individu untuk mengatur keinginan, kegemaran maupun tekanan yang muncul dalam diri individu sehingga ia mampu membedakan antara sesuatu yang harus dan tidak harus untuk dikerjakan.

3. Optimis, yakni sikap percaya bahwa kegagalan bukanlah akhir, tetapi mencoba untuk mengolah mindset yang positif sehingga masa depannya akan bersinar cemerlang.

4. Analisis Sebab-Akibat, yakni kapabilitas individu dalam mengidentifikasi hal-hal apa saja yang menyebabkan suatu permasalahan itu bisa terjadi, dan ia juga mampu memahami hal-hal apa saja yang bisa dilkukan untuk mengatasi masalah tersebut.

5. Empati, yakni rasa peduli yang dimiliki individu kepada orang lain

6. Efikasi Diri, yakni hasil dari pengentasan masalah yang berhasil

7. Reaching Out, yakni keyakinan seseorang bahwa pasti ada nilai positif yang bisa diambil dari kesulitan-kesulitan yang ia alami.

\section{B. Dukungan Sosial}

Dukungan sosial ialah sebuah pemberian rasa damai, atensi, apresiasi, atau memberikan pertolongan kepada seorang individu yang dilakukan oleh perseorangan maupun kelompok (Sarafino \& Smith, 2016). Dukungan sosial berarti ikatan antar-perseorangan yang didalamya berupa memberikan pertolongan dengan menyertakan beberapa aspek berupa sebuah informasi, atensi secara emosional, apresiasi, dan bantuan instrumental yang didapatkan seseorang lewat interaksi antara ia dan lingkungannya (Kumalasari \& Ahyani, 2012). Sedangkan Indrawati et al. (2010) mendefinisikan dukungan sosial sebagai suatu ungkapan yang dipakai dalam menjelaskan bagaimana hubungan transfer nilai positif kepada individu yang nantinya akan memberikan manfaat bagi kesehatan individu tersebut, baik kesehatan fisik maupun kesehatan mentalnya.

Dukungan sosial didefinisikan sebagai suatu kesan yang diterima oleh individu yang berupa rasa nyaman, diberikan perhatian, merasa dihargai, dihormati, serta dicintai dan disayangi oleh orang-orang disekitar yang dekat dengannya (Mufidah, 2017a). Sedangkan menurut Ogden (2007), dukungan sosial didefinisikan sebagai kuantitas dari teman yang dipunyai oleh seorang individu. Dukungan sosial bisa diterima dari orang-orang yang memiliki ikatan yang dekat, erat dan bermakna bagi individu tersebut, seperti sosok keluarga, sahabat, suami atau istri, saudara, tetangga sekitar rumah, dan rekan di tempat kerja (Oktaviana, 2013). Dukungan sosial sangat diperlukan oleh setiap individu karena manusia sendiri sejatinya diciptakan sebagai makhluk yang saling berhubungan dan membutuhkan satu sama lain (Mufidah, 2017b). Dukungan sosial yang didapatkan oleh seorang individu akan memberikan kesan bahwa ia merasa lebih nyaman, diberi perhatian, dirangkul, diberi rasa cinta dan kasih sayang, sehingga hal tersebut akan efektif dalam menangani tekanan di masa sulit dan menantang (Rif'ati et al., 2008). 
Terdapat beberapa aspek dalam dukungan sosial. Aspek dukungan sosial tersebut yaitu dukungan emosional, dukungan penghargaan, dukungan instrumental, dan dukungan informatif. Dukungan emosional disini mencakup pada perasaa empati, rasa peduli, dan pemberian atensi kepada individu. Dukungan emosional ini bisa berupa pemberian atensi dan mau menyimak curhatan dan keluh kesah orang lain. Dukungan penghargaan bisa melalui ungkapan hormat atau apresiasi positif kepada individu, serta membandingkan individu tersebut dengan individu lain dalam konteks yang positif. Dukungan instrumental mencakup pertolongan secara langsung kepada orang lain, dimana dukungan instrumental ini seperti memberikan pinjaman uang kepada mereka yang sedang membutuhkannya atau membantu untuk mengerjakan suatu pekerjaan. Dukungan informatif mencakup pada pemberian nasehat, saran, kritikan yang membangun, petunjuk, maupun umpan balik kepada orang lain, sehingga individu tersebut akan mencoba mencari jalan keluar dari setiap masalah yang sedang terjadi (House; Isfaiyah et al., 2019)

\section{Peran Dukungan Sosial Terhadap Resiliensi}

Tingkat resiliensi seseorang itu berpengaruh pada bagaimana ia selanjutnya, remaja yang memiliki resiliensi yang tinggi tentu akan tumbuh dan berkembang menjadi seorang yang resilien pula di masa mendatang. Sedangkan bagi remaja yang mempunyai resiliensi yang rendah, tentu akan mengalami kesulitan untuk pulih dan bangkit dari keterpurukan dan kesulitan yang dialami serta kurang dapat mengontrol dirinya sendiri (Barbarosa et al., 2021). Resiliensi yang tinggi dalam diri seseorang dapat berdampak positif pada beberapa hal antara lain kesehatan fisik, sehat dalam perilaku, performa dalam edukasi, pekerjaan, penghasilan/pendapatan, serta penurunan tindak kriminalitas. Sedangkan resiliensi yang rendah akan berdampak pada self esteem yang rendah, kemungkinan untuk bunuh diri, serta mengakibatkan depresi (Fadhillah et al., 2017). Ketika seorang individu memiliki tingkat resiliensi yang tinggi dalam dirinya, maka ia dapat menemukan solusi atas permasalahan yang terjadi, potensi dirinya mengalami peningkatan, menjadikan individu tersebut lebih optimis, lebih berani, serta kematangan emosinya pun akan tinggi (Oktaviana, 2013).

Lingkungan merupakan sesuatu yang akan membuat remaja merasa diterima, dihargai, dan dihormati, sehingga hal tersebut membuat remaja akan merasa bahwa ia berharga, baik bagi pribadinya sendiri maupun orang lain (Masnina, 2017). Seorang individu yang menerima dukungan sosial, entah dari keluarga, kawan/sahabat, atau lingkungan sekitarnya mempunyai kapabilitas dalam menghadapi tantangan dan kesukaran lebih baik daripada individu yang kurang menerima dukungan sosial (Maharani \& Hartati, 2021). Dukungan sosial bisa berupa banyak hal, seperti bisa berupa pemberian semangat, atensi, apresiasi, pertolongan serta rasa cinta kasih sayang yang akan membuat individu tersebut merasa bahwa dirinya diterima oleh lingkungan sekitar dan merasa diapresiasi dengan baik, sehingga individu tersebut dapat membentuk keyakinan yang positif dalam dirinya, lebih menghargai dirinya sendiri, serta lebih siap dan mampu menghadapi permasalahan maupun kesulitan yang dialaminya (Barbarosa et al., 2021). Dukungan sosial dapat memberikan dampak positif kepada seorang individu yang antara lain subjective well being yang meningkat, membantu dalam proses penyesuaian diri, meningkatkan kualitas diri, berkurangnya tingkat stres, serta meningkatkan dan memeilihara kesehatan tubuh (Oktaviana, 2013)

Bagi remaja panti asuhan, bisa diketahui dengan jelas bahwa lingkungan sosial yang paling utama bagi mereka ialah lingkungan panti asuhan, disana mereka dapat belajar dan mendapat pengalaman mengenai bagaimana bersosialisasi dengan baik dengan kawan-kawan ataupun pengasuh di panti asuhan (Kumalasari \& Ahyani, 2012). Remaja panti asuhan ketika mendapatkan dukungan sosial yang melimpah dari lingkungan sekitarnya, baik dari kawan-kawan maupun pengasuh di panti asuhan maka akan membuat dia dapat menciptakan kepribadian yang kuat serta memiliki orientasi menuju ke arah yang positif, dan nantinya dia akan mempunyai kemampuan untuk beradaptasi secara seimbang terhadap dirinya sendiri dan lingkungan sekitarnya (Mulia et al., 2014). Sedangkan remaja yang mendapatkan dukungan sosial terbatas akan memiliki persepsi bahwa dirinya diasingkan atau ditolak yang nantinya akan menyebabkan perasaan pesimis dan mudah menyerah dalam menghadapi kesulitan dalam hidupnya (Pahlevi et al., 2017).

Hasil dari penelitian yang telah dilaksanakan oleh Barbarosa et al. (2021) menunjukkan bahwa antara dukungan sosial dan resiliensi terdapat hubungan secara positif. Hasil dari penelitian lain yang dilaksanakan oleh Mulia et al. (2014) juga menunjukkan bahwa terdapat hubungan antara dukungan sosial teman sebaya terhadap tingkat resiliensi remaja panti asuhan. Selanjutnya, penelitian yang dilaksanakan oleh Muliawiharto \& Masykur (2020) memperoleh hasil bahwa terdapat hubungan secara positif dan signifikan antara dukungan emosianal pengasuh dengan resiliensi remaja panti asuhan. Melalui hasil tersebut menujukkan bahwa ketika dukungan soial yang diterima semakin tinggi maka tingkat resiliensi seseorang semakin tinggi, begitupun sebaliknya, ketika dukungan sosial yang diterima semakin rendah maka tingkat resilieni seseorang akan semakin rendah pula.

\section{KESIMPULAN}

Berdasarkan beberapa penjelasan diatas menunjukkan bahwa dukungan sosial memiliki pengaruh dalam meningkatkan resiliensi pada remaja panti asuhan. Resiliensi sangat diperlukan bagi remaja sebagai generasi muda penerus bangsa karena dengan menjadi pribadi yang resilien maka ia akan mampu bangkit dari keterpurukan dan kesulitan yang dihadapi. Terdapat banyak faktor dalam upaya meningkatkan resiliensi, dan dukungan sosial menjadi salah satunya. Dukungan sosial ini bisa diperoleh dari keluarga, teman, maupun orang lain yang dekat dengan kita. Dukungan sosial sendiri bisa berupa pemberian rasa 
Website : http://sosial.unmermadiun.ac.id/index.php/sosial

nyaman dan kehangatan, apresiasi, apresiasi maupun pertolongan yang diberikan oleh perseorangan ataupun kelompok kepada orang lain.

\section{UCAPAN TERIMAKASIH}

Peneliti mengucapkan banyak terima kasih kepada Prof. Dr. Abdul Muhid, M.Si sebagai dosen pengampu mata kuliah Pemberdayaan Psikologis II, serta teman-teman kelas G2.5 yang membantu dalam proses penelitian ini, sehingga penulis mampu menyelesaikan penelitian ini dengan baik.

\section{DAFTAR PUSTAKA}

Alvina, S., \& Dewi, F. I. R. (2017). Pengaruh Harga Diri Dan Dukungan Sosial Terhadap Resiliensi Mahasiswa Dengan Pengalaman Bullying Di Perguruan Tinggi. Psibernetika, 9(2). https://doi.org/10.30813/psibernetika.v9i2.472

Apelian, E., \& Nesteruk, O. (2017). Reflections of Young Adults on the Loss of a Parent in Adolescence. International Journal of Child, Youth and Family Studies, 8(3/4), 79. https://doi.org/10.18357/ijcyfs83/4201718002

Barbarosa, K., Putri, N. M. D., \& Chusairi, A. (2021). Hubungan Antara Dukungan Sosial dengan Resilensi pada Remaja Awal Penghuni Panti Asuhan Bani Yaqub Surabaya. Syntax Literate: Jurnal Ilmiah Indonesia, 6(7).

Dewi, G. K., \& Henu, B. (2015). Resiliensi pada Remaja Yatim Piatu yang Tinggal di Panti Asuhan. Jurnal SPIRITS, 5(2), 2936.

Ester, E., Atrizka, D., \& Putra, A. I. D. (2020). Peran Self Disclosure terhadap Resiliensi pada Remaja di Panti Asuhan. Psychopolytan: Jurnal Psikologi, 3(2), 119-125. https://doi.org/10.36341/psi.v3i2.1168

Fadhillah, A. R., Uyun, Q., \& Sulistyarini, I. (2017). Pengaruh Terapi Kognitif Perilaku Berbasis Kekuatan terhadap Peningkatan Resiliensi pada Remaja Panti Asuhan. Jurnal Intervensi Psikologi (JIP), 9(1), 96-106. https://doi.org/10.20885/intervensipsikologi.vol9.iss1.art7

Grotberg, E. H. (Edith H. (1995). A guide to promoting resilience in children: strengthening the human spirit (Issue 8).

Indrawati, S., Maslihah, S., \& Wulandari, A. (2010). Studi tentang Religiusitas, Derajat Stres, dan Strategi Penanggulangan Stres (Coping Stres) pada Pasangan Hidup Pasien Gagal Ginjal yang Menjalani Terapi Hemodialisa.

Isfaiyah, Rahmawati, \& Dalimunthe, R. Z. (2019). Hubungan dukungan sosial teman sebaya dengan resiliensi siswa serta implikasi terhadap bimbingan pribadi sosial. Jurnal Penelitian Dan Bimbingan Konseling, 4(2), 157-165.

Kumalasari, F., \& Ahyani, L. N. (2012). Hubungan Antara Dukungan Sosial Dengan Penyesuaian Diri Remaja Di Panti Asuhan. Jurnal Psikologi Pitutur, 1(1).

Maharani, P. C. D., \& Hartati, M. T. S. (2021). Hubungan Antara Self Efficacy Dan Dukungan Sosial Dengan Resiliensi Siswa Smk Negeri 1 Wonosegoro Kabupaten Boyolali Tahun Pelajaran 2020/2021. Empati-Jurnal Bimbingan Dan Konseling, 8(2), 12-25. https://doi.org/10.26877/empati.v8i2.7979

Masnina, R. (2017). Studi Analisis Tentang Resiliensi Terkait Harga Diri dan Sosial Kognitif pada Remaja Panti Asuhan Anak Harapan Samarinda. Jurnal Ilmu Kesehatan, 5(2), 144-150. https://doi.org/10.30650/jik.v5i2.65

Mazaya, K. N., \& Supradewi, R. (2011). Konsep Diri Dan Kebermaknaan Hidup Pada Remaja Di Panti Asuhan. Proyeksi, 6(2), 103. https://doi.org/10.30659/p.6.2.103-112

Mufidah, A. C. (2017a). Hubungan antara dukungan sosial dan resiliensi dengan locus of control sebagai moderator pada mahasiswa bidikmisi. Psikodimensia, 16(2), 121-130.

Mufidah, A. C. (2017b). Hubungan Antara Dukungan Sosial Terhadap Resiliensi Mahasiswa Bidikmisi Dengan Mediasi Efikasi Diri. Jurnal Sains Psikologi, 6(2), 69-75. https://doi.org/10.17977/um023v6i22017p069

Mulia, L. O., Elita, V., \& Woferst, R. (2014). Hubungan dukungan sosial teman sebaya terhadap tingkat resiliensi remaja di panti asuhan. JOM Psikologi, 1(2), 1-9.

Muliawiharto, A., \& Masykur, A. M. (2020). Hubungan Antara Dukungan Emosional Pengasuh Dengan Resiliensi Pada Remaja. Jurnal Empati, 8(4), 46.

Nisa, M. K., \& Muis, T. (2016). Studi tentang daya tangguh (resiliensi) anak di panti asuhan sidoarjo. Jurnal BK Unesa, 6(3), $40-44$.

Ogden, J. (2007). Health Psychology: A Textbook (4th Editio). McGraw-Hill.

Oktaviana, A. (2013). Hubungan locus of control dan dukungan sosial dengan resiliensi pada remaja penyandang tuna rungu. Psikoborneo: Jurnal Ilmiah Psikologi, 1(1), 1-5.

Pahlevi, R., Yuwono, D., Sugiharto, P., \& Jafar, M. (2017). Prediksi Self-Esteem, Social Support dan Religiusitas terhadap Resiliensi. Jurnal Bimbingan Konseling, 6(1), 90-93.

Portzky, M., Wagnild, G., De Bacquer, D., \& Audenaert, K. (2010). Psychometric evaluation of the Dutch Resilience Scale RS$\mathrm{nl}$ on 3265 healthy participants: A confirmation of the association between age and resilience found with the Swedish version. Scandinavian Journal of Caring Sciences, 24(SUPPL. 1), 86-92. https://doi.org/10.1111/j.14716712.2010.00841.x

Purwanti, W., \& Aulia, L. A.-A. (2017). Perbedaan Resiliensi antara Remaja yang Hidup dalam Keluarga Lengkap, Keluarga Single Parent, dan Remaja yang Hidup di Panti Asuhan. Jurnal Psikologi, 4(2), 62-70.

Rif'ati, M. I., Arumsari, A., Fajriani, N., Maghfiroh, V. S., Abidi, A. F., Chusairi, A., \& Hadi, C. (2008). Konsep Dukungan 
Website : http://sosial.unmermadiun.ac.id/index.php/sosial

Sosial. Academia, 118-212. https://d1wqtxts1xzle7.cloudfront.net/57586927/Konsep_Dukungan_Sosial-with-cover-pagev2.pdf?Expires $=1630155388 \&$ Signature $=\mathrm{HNgM}-$ mu2Qe4BfvLZpWcZQNeGIWOH8EKyRwJmBHhHrehHxP2c4xYKZ9zIKExmMUk6j259RyepQg0aP209QFxIoyQNg8 $\sim \mathrm{I} \sim \mathrm{B} 7 \mathrm{X6HVe15qD11Pb9OS6FeBcwlvge019v3XDirJXt}$

Sarafino, E. P., \& Smith, T. W. (2016). Health Psychology: Biopsychosocial Interaction. John Wiley \& Sons.

Setiawan, K. (2021, August 24). Kemensos Berikan Perlindungan Kepada 4 Jutaan Anak Yatim Piatu. Kemensos RI. https://kemensos.go.id/kemensos-berikan-perlindungan-kepada-4-jutaan-anak-yatim-piatu

Setyowati, A., Hartati, S., \& Sawitri, D. R. (2010). Resiliensi Pada Siswa Penghuni Rumah Damai. Psikologi Undip, 7(1), 6777.

Sun, J., \& Stewart, D. (2007). Age and Gender Effects on Resilience in Children and Adolescents. International Journal of Mental Health Promotion, 9(4), 16-25. https://doi.org/10.1080/14623730.2007.9721845

Syifa, F., Santoso, D. B., \& Hambali, I. (2021). Hubungan Dukungan Sosial Teman Sebaya dengan Resiliensi Pada Peserta Didik Kelas XI di SMK Negeri 1 Glagah Banyuwangile. Jurnal Pembelajaran, Bimbingan, Dan Pengelolaan Pendidikan, $1(5), 356-361$.

Tricahyani, I. A. R., \& Widiasavitri, P. N. (2016). Hubungan antara dukungan sosial dengan penyesuaian diri pada remaja awal di Panti Asuhan Kota Denpasar. Jurnal Psikologi Udayana, 3(3), 542-550.

Tunliu, S. K., Aipipidely, D., \& Ratu, F. (2019). Dukungan Sosial Keluarga Terhadap Resiliensi pada Narapidana di Lembaga Pemasyarakatan Klas IIA Kupang. Journal of Health and Behavioral Science, 1(2), 68-82. https://doi.org/10.35508/jhbs.v1i2.2085

Walsh, F. (2006). Strengthening Family Resilience. The Gulford Press.

Wasono, C. W. (2019). Pengaruh Resiliensi terhadap Harga Diri Remaja di Panti Asuhan Yatim dan Tunanetra Muhammadiyah Purworejo. Acta Psychologia, 1(1), 1-14. https://doi.org/10.21831/ap.v1i1.43466 